\title{
Dynamics of changes in the content of thyroid hormones and some neurotransmitters in brain of rats with experimental Alzheimer's disease
}

\author{
Tatiana Gorbach ${ }^{1}$, Galina Gubina-Vakyulyk ${ }^{2}$, Oksana Nakonechna ${ }^{1}$, Anton Tkachenko ${ }^{1}$
}

${ }^{1}$ Department of biochemistry, Kharkiv National Medical University, Kharkiv Ukraine

${ }^{2}$ Department of Pathological anatomy, Kharkiv National Medical University, Kharkiv Ukraine
This work is licensed under a Creative Commons Attribution 4.0 International License

Received: 08-08-2017

Accepted: 21-11-2017

UDC 616.831.31- 078:57.083.185'175.44:577. 175.82:616.894- 053.8-092.9
J Clin Med Kaz 2017;4(46):26-32

Автор для корреспонденции: Ткаченко Антон Сергеевич, к. мед. н., асистент кафедры биохимии, Харьковский национальный медицинский университет, г. Харьков, Украина, Тел: +38-050-109-45-54, E-mail: antontkachenko555@gmail.com
Abstract

Objective: Alzheimer's disease is one of the most common neurodegenerative diseases, and mechanisms of its development have been studied for many years. The aim of the research was to study the content of thyroid-stimulating hormone (TSH), thyroid hormones and tau protein in the blood serum, as well as the content of thyroid hormones and some neurotransmitters in the cerebral cortex in the dynamics of experimental Alzheimer's disease in rats.

Materials and methods. The experiment was performed on 45 WAG rats, which were divided into 3 groups. The first group was the control one. Animals from the second and third groups were intraperitoneally administered with scopolamine for 14 and 27 days, which led to the development of Alzheimer's disease. Brain homogenate was prepared. Concentrations of T3, T4 in blood serum and homogenates of the cerebral cortex, as well as TSH and tau protein in serum, were determined by ELISA. Determination of the content of neurotransmitter amino acids (aspartate and glutamate) was carried out by thin-layer chromatography. The content of dopamine and norepinephrine in the cerebral cortex homogenate was determined by column chromatography, and acetylcholine levels were measured by spectrophotometry. Morphological examination included staining of brain tissue with congo-rot + hematoxylin.

Results. It was established that in cerebral cortex homogenates of rats with experimental Alzheimer's disease the T3 content was reduced, and T4 levels were similar to rats of the control group, which in combination with the normal concentration of thyroid hormones in blood serum indicates the development of local hypothyroidism in the cerebral cortex. In rats with Alzheimer's disease, glutamic and aspartic acid levels were increased against the background of GABA reduction. There was also a decrease in the levels of noradrenaline and dopamine in the cerebral cortex homogenates, which contributes to the abnormal energy metabolism and impaired cognitive functions. Morphological study demonstrated the presence of congophilic masses in the brain tissue and in the walls of small arteries with the development of brain atrophy.

Conclusions. Alzheimer's disease caused by the administration of scopalamine is characterized by the development of local hypothyroidism in the cerebral cortex, an increase in the level of glutamic and aspartic acids with a decrease in GABA, a decrease in the level of dopamine and norepinephrine in the cerebral cortex.

Key words: Alzheimer's disease - thyroid hormones - neurotransmitters - rats. \footnotetext{
ҚАРҚЫНЫ

Т.В. Горбач ${ }^{1}$, Г.И. Губина-Вакулик ${ }^{2}$, О.А. Наконечная ${ }^{1}$, А.С. Ткаченко ${ }^{1}$

'Биохимия кафедрасы, Харьков ұлттық медициналық университеті, Харьков қаласы, Украина

${ }^{2}$ Патологиялық анатомия кафедрасы, Харьков ұлттық медициналық университеті, Харьков қаласы, Украина
}

АЛЬЦГЙМЕР ЭКСПЕРИМЕНТТІК АУРУЫЫНА ШАЛДЫҚҚАН ЕГЕУҚҰЙРЫҚТАРДЫН БАС МИЫ ҚАБЫҒЫНДАҒЫ ТИРЕОИДТІ ГОРМОНДАР МЕН КЕЙБІР НЕЙРОМЕДИАТРЛАР ҚҰРАМЫНЫН ӨЗГЕРУ

\section{ТҰЖЫРЫМДАМА}

Зерттеу мақсаты: Альцгеймер ауруы аса таралған нейродегенеративті аурулардың бірі болып табылады, олардың даму механизмі көптеген жылдар бойы зерттелуде. Зерттеудің мақсаты қан сарысуындағы тиреотропты гормондардың (ТТГ), тиреоидті гормондар мен таупротеиндердің мөлшерін, сондай-ақ егеуқұйрықта Альцгеймер эксперименттік ауруының даму қарқынында бас миы қабығындағы тиреоидті гормондар мен кейбір нейромедиаторлардың мазмұнын зерттеу болып табылды. 
Материалдар мен әдістер. Экспериментті WAG популяциясының 45 егеуқұйрығына жүргізілді, олар 3 топқа бөлінді. Бірінші - бақылау тобы болды. Екінші және үшінші топтардағы жануарларға ішперденің ішіне 14-27 күн бойы скополамин енгізілді, ол Альцгеймер ауруының дамуына алып келді. Эксперименттен шығарылғаннан кейін бас миының гомогенаты дайындалды. Бас миы қабығының қан сарысуы мен гомогенаттағы Т3, Т4 шоғырлануын, ТТГ және қан сарысуындағы тау-ақуыздары иммуноферментті әдіспен анықталды. Нейромедиаторлық амин қышқылдарының (аспартат пен глутаматтың) мөлшерін анықтауды жұқа қабатты хроматография әдісімен өткізді. Бас миы қабығының гомогенатында дофамин мен норадреналиннің мөлшерін қалыптық хроматография әдісімен, ал ацетилхолинді - спектрофотометриялық әдіспен анықтады. Морфологиялық зерттеу бас миының микропрепараттарын конго-рот-гематоксилинмен бояуды қамтыды.

Нәтижелері. Альцгеймер эксперименттік ауруына шалдыққан егеуқұйрықтардың бас миы қабығының гомогенатында Т3 мөлшері төмен екені, ал Т4 - бақылау тобындағы егеуқұйрықтардағы деңгейге сәйкес келеді, ол қан сарысуындағы тиреоидті гормондардың қалыпты шоғырлануымен үйлесімде бас миы қабығының жергілікті гипотиреозының дамуын көрсетеді. Альцгеймер ауруын модельдеу кезінде егеуқұйрықтарда гамма-амин майлы қышқылдарының (ГАМҚ) төмендеуі барысында глутамин және аспарагин қышқылдарының артуы байқалады. Сонымен қатар, бас миы қабығының гомогенаттарында норадреналин мен дофамин деңгейінің төмендеуі байқалды, ол энергетикалық метаболизм мен когнитивті қызметтердің бұзылуын тудырады. Морфологиялық зерттеу бас миы тіндерінде және бас миы атрофиясымен қатарлас дамитын ұсақ күретамырларының қабырғасында амилоидтің болуын көрсетті.

Тұжырымдар. Скополаминді енгізумен туындаған Альцгеймер ауруы бас миы қабығында жергілікті гипотиреоздың дамуымен, ГАМқ төмендеуі, бас миы қабығында дофамин мен норадреналин деңгейінің төмендеуі барысында глутаминдік және аспарагиндік қышқылдар деңгейінің артуымен сипатталады.

Түйінді сөздер: Альцгеймер ауруы - қалқанша безінің гормондары - нейромедиаторлар - егеуқұйрықтар

\section{ДИНАМИКА ИЗМЕНЕНИЯ СОДЕРЖАНИЯ ТИРЕОИДНЫХ ГОРМОНОВ И НЕКОТОРЫХ НЕЙРОМЕДИАТОРОВ В КОРЕ ГОЛОВНОГО МОЗГА КРЫС С ЭКСПЕРИМЕНТАЛЬНОЙ БОЛЕЗНЬЮ АЛЬЦГЕЙМЕРА}

\section{Т.В. Горбач ${ }^{1}$, Г.И. Губина-Вакулик ${ }^{2}$, О.А. Наконечная ${ }^{1}$, А.С. Ткаченко ${ }^{1}$}

${ }^{1}$ Кафедра биохимии, Харьковский национальный медицинский университет, г. Харьков, Украина

${ }^{2}$ Кафедра патологической анатомии, Харьковский национальный медицинский университет, г. Харьков, Украина

\section{PЕЗЮМЕ}

Цель исследования: Болезнь Альцгеймера является одним из наиболее распространенных нейродегенеративных заболеваний механизмы развития которого изучаются на протяжении многих лет. Целью исследования явилось изучение содержания тиреотропного гормона (ТТГ), тиреоидных гормонов и тау-протеина в сыворотке крови, а также содержания тиреоидных гормонов и некоторых нейромедиаторов в коре головного мозга в динамике развития экспериментальной болезни Альцгеймера у крыс.

Материалы и методы. Эксперимент проводили на 45 крысах популяции WAG, которые были разделены на 3 группы. Первая группа была контрольной. Животным второй и третьей группы внутрибрюшинно вводили скополамин в течение 14 и 27 дней, что приводило к развитию болезни Альцгеймера. После выведения из эксперимента готовился гомогенат головного мозга. Концентрации Т3, T4 в сыворотке крови и гомогенате коры головного мозга, ТТГ и тау-белка в сыворотке крови определяли иммуноферментным методом. Определение содержания нейромедиаторных аминокислот (аспартат и глутамат) проводили методом тонкослойной хроматографии. Содержание дофамина и норадреналина в гомогенате коры головного мозга определяли методом колоночной хроматографии, а ацетилхолина - спектрофротометрически. Морфологическое исследование включало окрашивание микропрепаратов головного мозга конгорот+гематоксилином.

Результаты. Установлено, что в гомогенате коры головного мозга у крыс с экспериментальной болезнью Альцгеймера содержание Т3 достоверно снижено, а Т4 - соответствует уровню у крыс контрольной группы, что в сочетании с нормальной концентрацией тиреоидных гормонов в сыворотки крови указывает на развитие местного гипотиреоза в коре головного мозга. У крыс при моделировании болезни Альцгеймера отмечается повышение глутаминовой и аспарагиновой кислот при снижении гамма-аминомасляной кислоты (ГАМК). Также наблюдалось снижение уровень норадреналина и дофамина в гомогенатах коры головного мозга, что способствует нарушению энергетического метаболизма и когнитивных функций. Морфологическое исследование продемонстрировало наличие амилоида в ткани головного мозга и стенках мелких артерий с параллельно развивающейся атрофией головного мозга.

Выводы. Болезнь Альцгеймера, вызванная введением скополамина, характеризуется развитием локального гипотиреоза в коре головного мозга, повышением уровня глутаминовой и аспарагиновой кислот при снижении ГАМК, снижении уровня дофамина и норадреналина в коре головного мозга.

Ключевые слова: болезнь Альцгеймера - гормоны щитовидной железы - нейромедиаторы - крысы.

\section{Введение}

обой Болезнь

рогрессирующее

(БА) полиэтиологическое нейродегенеративное заболевание, в результате которого развивается деменция. Морфологически данная патология характеризуется формированием внутриклеточных нейрофибриллярных клубков и внеклеточных амилоидных белковых агрегатов, что вносит вклад в развитие сенильных бляшек [1]. БА является шестой по значимости причиной смерти в Соединенных Штатах Америки, став причиной $3,6 \%$ всех смертей в 2014 году [2]. На данный момент более 23 миллионов человек старше 65 лет во всем мире страдают БА, что составляет около $10 \%$ от населения планеты соответствующей возрастной группы. Именно пожилые люди подвергаются наибольшему риску развития БА. Так, в структуре заболеваемости лиц старше 85 лет БА занимает одно из лидирующих мест и уровень заболеваемости в данной возрастной группе составляет 30\% [3]. Повышение уровня жизни в развитых странах и, как следствие, увеличение средней продолжительности жизни вносит вклад в увеличение заболеваемости. Согласно современным прогнозам, рост числа пожилых людей приведет к увеличению числа впервые зарегистрированных случаев БА в четыре раза к 2050 году [2].

На данный момент единой теории этиологии БА не существует. Известны по меньшей мере три гипотезы в отношении причин развития БА. Исторически первой гипотезой является «холинергическая теория». Согласно данной концепции, БА вызвана нарушением образования нейромедиатора ацетилхолина [4]. Позднее появилась «амилоидная теория» развития БА, предложенная Ј.А. Hardy и G.A Higgins (1992), суть которой заключается в отложении в головном мозге аномального белка амилоида с формированием бляшек $[5,6]$. Согласно «тау-гипотезе», развитие БА сопровождается гиперфосфорилированием тау-белков с их агрегацией и последующим образованием нейрофибриллярных конгломератов [7].

Несмотря на кажущиеся различия гипотез, все они связаны метаболически: образование амилоида способствует фосфорилированию и образованию агрегатов тау-белка, а оба этих процесса приводят к развитию энергодефицита, окислительного стресса и нарушению 
протекания метаболических процессов в нейронах. Связующими звеньями, объединяющими все гипотезы, могут быть особенности содержания тиреоидных гормонов в структурах головного мозга, т.к. эти гормоны определяют уровень энергетических процессов, влияя на активность различных ферментов в нейронах. Известно, что дисфункция щитовидной железы может приводить к развитию обратимых когнитивных нарушений, и поэтому тиреотропный гормон (ТТГ) уже давно является частью скринингового лабораторного теста на деменцию в некоторых странах. Следует отметить, что в нескольких популяционных исследованиях продемонстрирована связь между тиреоидной дисфункцией и БА [8], что обуславливает интерес к изучению не только тиреоидного статуса организма больных БА в целом, но и локального влияния тиреоидных гормонов (Т3 и Т4) на головной мозг. А особенности содержания тиреоидных гормонов в головном мозге при БА не изучены.

Взаимодействие $\beta$-амилоидных олигомеров с нейротрансмиттерными системами приводит к развитию клеточной дисфункции, нарушению нейромедиаторного состава и, наконец, появлению неврологических признаков заболевания [1]. Помимо известных нарушений со стороны холинергических нейронов, развитие БА также ассоциировано с изменением функционирования глутаматергической системы [9]. Также обсуждается возможность вовлечения дофаминергической системы в патогенез БА. В некоторых экспериментальных работах показано, что дофаминергическая система вполне может играть роль в возникновение когнитивных дисфункций при БА [10]. Однако четкие представления о роли дофамина при БА всё еще отсутствуют.

Целью исследования явилось изучение содержания тиреотропного гормона (ТТГ), тиреоидных гормонов и тау-протеина в сыворотке крови, а также содержание тиреоидных гормонов и некоторых нейромедиаторов в коре головного мозга в динамике развития экспериментальной БА у крыс.

\section{Материалы и методы}

Экспериментальное исследование проведено на 45 половозрелых белых крысах популяции WAG, которые содержались в стандартных условиях вивария. Животные в случайном порядке были разделены на три группы по 15 крыс в каждой: 1) первая группа служила в качестве контроля и состояла из интактных животных; 2) у крыс второй группы моделировалась БА путем 14-дневного введения скополамина; 3) крысы третьей группы получали скополамин в течение 27 дней. Для моделирования заболевания животным внутрибрюшинно вводился скополамин (Sigma, США), ежедневно в дозе 1 мг/кг один раз в день [11], что приводило к развитию центрального холинергического дефицита [12], являющегося основным звеном в патогенезе БА [4].

Животных выводили из эксперимента путем декапитации под легким тиопенталовым наркозом (в дозе 50 мг/кг веса). Эксперименты проводили в соответствии с «Общими этическими принципами проведения экспериментов на животных», принятыми Первым Национальным конгрессом по биоэтике (Киев, Украина, 2001), VIII Директивой 2010/63/EU Европейского парламента и Совета Европейского Союза от 22.09.2010 г. по охране животных, использующихся в научных целях, и положениями Европейской конвенции «О защите позвоночных животных, которые используются для экспериментальных и других научных целей» (Страсбург, 1986).

После выведения животных из эксперимента у них извлекались большие полушария головного мозга, часть которых использовалась для приготовления гомогената. На льду отделялась кора, которая измельчалась и помещалась в стеклянный гомогенизатор Поттера. Для приготовления гомогената использовали $0,25 \mathrm{M}$ раствор сахарозы в 0,2 $\mathrm{M}$ трис- $\mathrm{HCl}$, содержащий 1 мМ ЭДТА и имеющий $\mathrm{pH}$ 7,4. Гомогенизацию проводили в течение 30 секунд на льду (скорость вращения составляла 1000 оборотов в минуту, зазор между стеклом и тефлоном составлял 0,2 мм). Суспензию центрифугировали в течение 10 минут $(1000$ g). Для биохимического исследования использовали полученный супернатант.

Концентрации Т3 и Т4 в гомогенате коры головного мозга и сыворотке крови определяли иммуноферментным методом с применением наборов фирмы «Вектор-Бест» (Российская Федерация), уровни тиреотропного гормона (ТТГ) в сыворотке крови - иммуноферментным методом с помощью набора фирмы «Bender MedSystems» (Австрия). Для определения содержания тау-белка в сыворотке крови пациентов также использовали ИФА-метод с применением набора реагентов фирмы «Invitrogen» (Канада). Исследования проводились в соответствии с инструкциями к используемым ИФА-наборам с помощью стрипового иммуноферментного анализатора «Awareness Technology Stat Fax 303 Plus» (США).

Определение содержания нейромедиаторных аминокислот (аспартат и глутамат) проводили методом тонкослойной хроматографии [13]. Для хроматографии использовали силиконовые пластины Silufol (Чешская Республика). При проведении хроматографии использовали системурастворителей $\mathrm{N}$-бутанол-ацетат-водавсоотношении 80:20:20 (по объему). Процесс разделения аминокислот повторяли 3 раза для лучшего фракционирования. Идентификацию аминокислот проводили с использованием Rf (коэффициент хроматографического разделения) для вышеупомянутых систем растворов, а также стандартного образца глутамата (Sigma, США).

В гомогенатах, полученных из коры головного мозга, спектрофотометрически определяли содержание ацетилхолина [14]. Содержание дофамина и норадреналина в гомогенатах коры головного мозга определяли методом колоночной хроматографии с последующим флюориметрическим анализом на спектрофлюориметре «Hitachi-М» (Япония) [15].

Левое полушарие головного мозга после извлечения из черепной коробки фиксировалось в 10\% нейтральном формалине. Используя парафиновый метод заливки, изготовляли микропрепараты, окрашивание производилось методом конго-рот+гематоксилин, т.е. осуществлялось хорошо известное и широко применяемое гистохимическое окрашивание на амилоид [16].

Для проведения статистической обработки данных применяли программу «GraphPad Prism 5». Критерий Колмогорова-Смирнова использовался для проверки гипотезы о принадлежности наблюдаемой выборки нормальному закону. Производились расчеты t-критерия Стьюдента. Достоверной считалась разница при $\mathrm{p}<0,05$. 


\section{Результаты.}

Проведенное нами изучение содержания ТТГ и тиреоидных гормонов в динамике развития экспериментальной БА показало, что на 15 день с момента начала введения скополамина содержание ТТГ, Т3 и Т4 в сыворотке крови крыс практически не отличается от их уровня в контрольной группе (табл. 1). В гомогенате коры головного мозга у крыс с экспериментальной БА содержание Т3 достоверно снижено, а Т4 - соответствует уровню у крыс контрольной группы (табл. 1).

Таблина 1 Содержание ТТГ в сыворотке крови крыс, Т3 и Т4 в сыворотке крови и гомогенатах коры головного мозга крыс при моделировании болезни Альцгеймера $(\mathrm{M} \pm \mathrm{m})$

\begin{tabular}{|c|c|c|c|c|c|}
\hline \multirow[t]{2}{*}{ Группы животных } & \multicolumn{3}{|c|}{ Сыворотка крови } & \multicolumn{2}{|c|}{ Гомогенат коры головного мозга } \\
\hline & Т3, нмоль/л & Т4, нмоль/л & ТТГ, МЕ/л & Т3, нмоль/г ткани & Т4, нмоль/г ткани \\
\hline $\begin{array}{l}\text { Контрольная группа } \\
(\mathrm{n}=15)\end{array}$ & $2,48 \pm 0,22$ & $84,72 \pm 6,00$ & $1,95 \pm 0,12$ & $0,36 \pm 0,01$ & $15,00 \pm 1,22$ \\
\hline $\begin{array}{l}\text { Крысы с БА, } 14 \text { день } \\
(n=15)\end{array}$ & $\begin{array}{l}2,39 \pm 0,19 \\
p>0,05\end{array}$ & $\begin{array}{l}82,33 \pm 5,21 \\
p>0,05\end{array}$ & $\begin{array}{l}1,84 \pm 0,11 \\
p>0,05\end{array}$ & $\begin{array}{l}0,29 \pm 0,01 \\
p<0,05\end{array}$ & $\begin{array}{l}16,31 \pm 1,15 \\
p>0,05\end{array}$ \\
\hline Крысы с БА, 27 день & $2,53 \pm 0,19$ & $86,13 \pm 7,11$ & $2,09 \pm 0,14$ & $0,21 \pm 0,01$ & $27,22 \pm 1,34$ \\
\hline$(n=15)$ & $\mathrm{p}>0,05$ & $\mathrm{p}>0,05$ & $\mathrm{p}>0,05$ & $\mathrm{p}<0,02$ & $\mathrm{p}<0,02$ \\
\hline
\end{tabular}

p -вероятность отличия показателя с контрольной группой

Установлено, что в этот период исследований таупротеин в сыворотке крови не определяется (то есть не наблюдается выраженного разрушения нейронов). Морфологические исследования не выявили наличие ßамилоида, содержание ацетилхолина достоверно снижено $(1,79 \pm 0,11$ мкг/г ткани у крыс второй группы с БА при уровне $2,96 \pm 012$ мкг/г ткани у животных контрольной группы), когнитивные нарушения не выявлены. Следовательно, снижение трийодтиронина в коре головного мозга крыс является одним из ранних проявлений заболевания.

Из литературных данных известно, что Т3 регулирует уровень и осуществляет модуляцию астроцитарного транспорта глутамата [17]. В связи с этим представляло интерес изучить содержание глутамата и гаммааминомасляной кислоты (ГАМК) в коре головного мозга при развитии БА. Данные наших исследований свидетельствуют о том, что уровень глутаминовой кислоты на 15 день с момента начала введения скополамина достоверно повышается на $40,5 \%$, а содержание ГАМК снижается на 25,5 \% (табл. 2). Содержание другой нейротрансмиттерной аминокислоты аспарагиновой - в этот период эксперимента соответствует уровню у животных контрольной группы (табл. 2).

Таблица 2 Содержание нейромедиаторов в гомогенатах коры головного мозга крыс при экспериментальной болезни Альцгеймера $(\mathrm{M} \pm \mathrm{m})$

\begin{tabular}{|c|c|c|c|}
\hline $\begin{array}{l}\text { Группы крыс, } \\
\text { единицы измерения }\end{array}$ & $\begin{array}{c}\text { Контрольная группа } \\
(\mathrm{n}=15)\end{array}$ & $\begin{array}{l}\text { Крысы с БА, } 14 \text { день } \\
(\mathrm{n}=15)\end{array}$ & Крысы с БА, 27 день (n=15) \\
\hline $\begin{array}{l}\text { Глутамат, } \\
\text { мкМ/г ткани }\end{array}$ & $13,82 \pm 1,09$ & $\begin{array}{l}19,41 \pm 1,38 \\
p<0,02\end{array}$ & $\begin{array}{l}27,48 \pm 1,18 \\
p<0,001\end{array}$ \\
\hline $\begin{array}{l}\text { Аспартат, } \\
\text { мкМ/г ткани }\end{array}$ & $3,87 \pm 0,22$ & $\begin{array}{l}4,05 \pm 0,18 \\
p>0,05\end{array}$ & $\begin{array}{l}6,71 \pm 0,45 \\
p<0,001\end{array}$ \\
\hline $\begin{array}{l}\text { ГАМК, } \\
\text { мкМ/г ткани }\end{array}$ & $8,79 \pm 0,34$ & $\begin{array}{l}6,45 \pm 0,22 \\
p<0,05\end{array}$ & $\begin{array}{l}3,98 \pm 0,18 \\
p<0,001\end{array}$ \\
\hline $\begin{array}{l}\text { Норадреналин, } \\
\text { нМ/г ткани }\end{array}$ & $1,38 \pm 0,12$ & $\begin{array}{l}1,26 \pm 0,09 \\
p>0,05\end{array}$ & $\begin{array}{l}0,89 \pm 0,07 \\
p<0,02\end{array}$ \\
\hline $\begin{array}{l}\text { Дофамин, } \\
\text { нМ/г ткани }\end{array}$ & $0,56 \pm 0,03$ & $\begin{array}{l}0,53 \pm 0,02 \\
p>0,05\end{array}$ & $\begin{array}{l}0,44 \pm 0,02 \\
p<0,01\end{array}$ \\
\hline
\end{tabular}

Примечание: $\mathrm{p}$ - достоверность по сравнению с контрольной группой

Важная роль в развитии когнитивных нарушений при БА отводится биогенным аминам, в частности норадреналину и дофамину, на содержание и обмен которых также влияют тиреоидные гормоны [19]. Изучение содержания биогенных аминов в гомогенате головного мозга крыс показало, что на 15 сутки с момента начала эксперимента содержание норадреналина и дофамина у крыс, которым вводили скополамин, не отличается от их содержания у животных контрольной группы (табл. 2).

Более продолжительное ежедневное введение скополамина (на протяжении 27 дней) приводит к значительному снижению содержания ацетилхолина в гомогенатах коры головного мозга крыс $(1,02 \pm 0,07$ мкг/г ткани против 2,96 $\pm 0,12$ мкг/Г ткани у крыс контрольной группы), появлению в сыворотке крови тау-протеина (1,58 $\pm 0,09$ нг/мл, у крыс контрольной группы не выявлен) и развитию когнитивных нарушений [12], что характерно для БА. Определение содержания ТТГ, а также Т3 и Т4 в сыворотке крови крыс в этот период исследования показало, что уровень ТТГ, Т3 и Т4 у крыс с экспериментальной БА практически не отличается от их содержания у здоровых крыс контрольной группы и у крыс с БА на 15 сутки эксперимента (табл. 1). В гомогенатах коры головного мозга крыс отмечается выраженное снижение содержания Т3 и 
повышение Т4, что свидетельствует о дальнейшем развитии местного гипотиреоза, связанного со снижением активности тканевой дейодиназы (табл. 1).

Определение содержания биогенных аминов, играющих значительную роль в регуляции метаболических процессов в головном мозге и влияющих на когнитивные функции, показало, что при хроническом введении скополамина у животных третьей группы отмечается статистические достоверное снижение концентрации как норадреналина на 35,5\%, так и дофамина на 21,4\% (табл. 2). Полученные нами данные соответствуют литературным сведениям о влиянии тиреоидных гормонов на синтез биогенных аминов [10].

Одновременно проведенное гистохимическое исследование ткани головного мозга с использованием специфической окраски на амилоид (конгорот+гематоксилин) позволило подтвердить факт развития амилоидоза головного мозга у животных при многократном (27 дней) внутрибрюшинном введении скополамина. На представленном рисунке конгофильные массы полностью заместили стенку мелкой артерии, просвет которой стал очень узким (рис. 1). Ткань головного мозга в окружении этого сосуда также конгофильна, присутствия нейронов или нейроглии - не наблюдается.

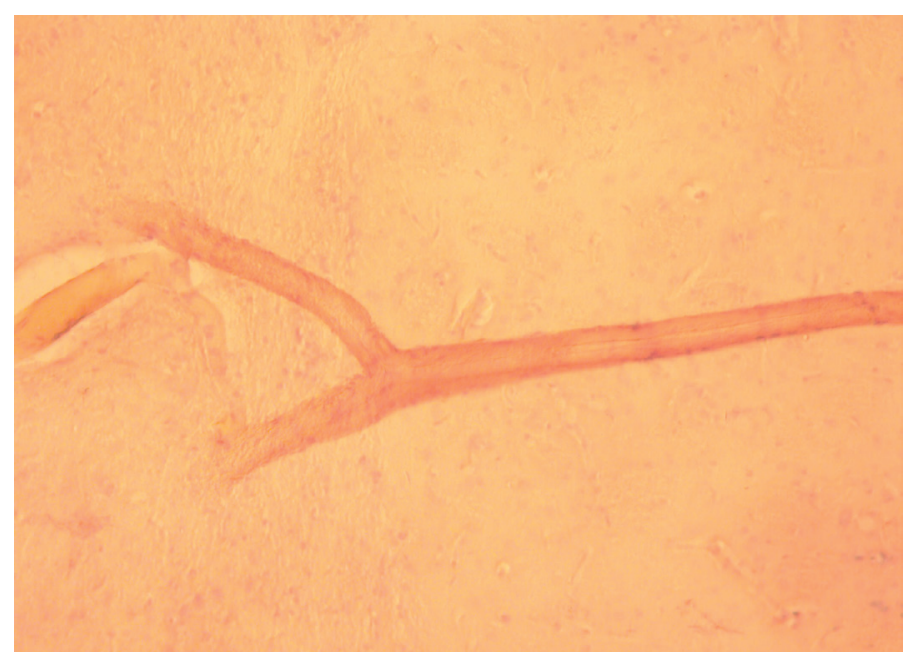

Рисунок 1 - Наличие конгофильных масс в стенке мелкой артерии и окружающей ткани головного мозга у животного третьей группы. Окрашивание конго-рот + гематоксилин. Ув. 400.

Bсе эти изменения происходят на фоне снижения концентрации биогенных аминов (как следствие локального гипотиреоза), что усугубляет метаболические нарушения и способствует появлению когнитивных дисфункций.

\section{Обсуждение}

Полученные данные свидетельствуют о том, что у крыс с экспериментальной БА на фоне эутиреоидного состояния организма развивается местный гипотиреоз в коре головного мозга, что, по-видимому, связано со снижением активности тканевой дейодиназы.

Местное снижение трийодтиронина в гомогенатах коры головного мозга может изменить количество и модифицировать активность ферментов, участвующих в гликолизе и аэробном митохондриальном окислении глюкозы (главного энергетического субстрата в головном мозге). Вероятно с этим связано установленное рядом авторов снижение потребления глюкозы головным мозгом при БА [19]. Известно, что для головного мозга характерен высокий уровень энергетического обмена, практически все функции мозга энергозависимы, в связи с этим можно предположить, что вывяленный нами местный гипотиреоз является важным фактором, способствующим снижению энергообразования и, в связи с этим, гибели нейронов. Образование $\beta$ - амилоида также играет важную роль в развитии энергодефицита, так как $\beta$-амилоид является антагонистом инсулинового рецептора (т.е снижает поступление глюкозы в ткань мозга), отложение амилоида в сосудах приводит к нарушению кровотока и способствует развитию тканевой гипоксии и снижению доставки энергетических субстратов. По-видимому, именно низкий уровень АТФ является причиной снижения активности ацетилхолинтрансферазы и аксонального транспорта ацетилхолина, что, как известно, является причиной, развития и прогрессирования БА.

Известно, что чрезмерное фосфорилирование тау-белка ведет к образованию нейрофибриллярных клубков, что рассматривается как ведущий процесс, лежащий в основе таупатий (в том числе БА). Основным ферментом, катализирующим фосфорилирование таубелка, является киназа гликогенсинтетазы-3 (КГС-3). С изменением ее активности связывают возможность гиперфосфорилирования тау-белка и его конформационные изменения, способствующие формированию агрегатов. Активатором КГС-3 является Аb-амилоидный пептид, который может действовать как антагонист инсулинового рецептора и повышать активность КГС-3. В то же время известно, что ингибитором КГС-3 является трийодтиронин, определяющий уровень энергообразования в головном мозге, влияющий на липидный и углеводный обмен. В связи с этим можно предположить, что важную роль в процессе образования нейрофибриллярных клубков при БА играет выявленное нами снижение содержания трийодтиронина в гомогенатах коры головного мозга крыс.

Известно, что HSP 70 (белок теплового шока c молекулярной массой 70 кДа), обладающий цитопротекторными и антиапоптотическими свойствами, является определяющим компонентом эндогенной защиты головного мозга от повреждений [20]. Синтез этого белка, как установлено, снижается при уменьшении поступления трийодтиронина в клетки мозга [21]. Можно ожидать, что при выявленном нами местном гипотиреозе в гомогенате коры головного мозга крыс при моделировании БА снижено содержание HSP 70, что при энергодефиците является причиной гибели нейронов и развития когнитивных нарушений.

Установлено, что значительную роль в регуляции метаболических процессов в головном мозге играют нейромедиаторные аминокислоты, особенно в условиях холинэргического дефицита [22]. Данные проведенных нами исследований свидетельствуют о том, что при введении скополамина крысам в течение 27 дней в гомогенатах коры головного мозга значительно повышается содержание глутаминовой и аспарагиновой кислот соответственно в 2 и в 1,75 раз, а также в 2,2 раза снижается содержание ГАМК (табл. 2). Наши данные соответствуют литературным данным о повышении уровня глутаминовой кислоты в мозге при БА [9]. Известно, что глутаминовая и аспарагиновая аминокислоты эксайтотоксичны [23], возможно, что именно 
с их влиянием связано снижение активности дейодиназ в клетках коры головного мозга. Это предположение косвенно подтверждается имеющимися в литературе сведениями о снижении 5-дейодиназы в ЦНС при депрессивных состояниях, сопровождающихся повышенным уровнем глутамата [24].

Известно, что Т3 влияет на активность глутаматдекарбоксилазы, при гипотиреозе активность фермента снижается [25]. Возможно, наблюдаемое снижение уровня ГАМК в гомогенате коры головного мозга при экспериментальной БА связано также с уменьшением активности глутаматдекарбоксилазы в связи со сниженным содержанием Т3..

Высокие концентрации аспарагиновой и глутаминовой кислот способствуют развитию митохондриальной дисфункции, снижению энергообразования, и, вследствие этого, гибели нейронов. Снижение содержания трийодтиронина в гомогенатах коры головного мозга также способствуют низкоэнергетическому сдвигу в адениловой системе, усугубляя влияние аминокислот, ускоряя развитие заболевания.

Таким образом, проведенное нами исследование позволяет предположить, что важным фактором в патогенезе экспериментальной БА является местный гипотиреоз, возникающий в коре головного мозга крыс. Низкий уровень Т3 в гомогенате коры головного мозга способствует уменьшению активности глутаматдекарбоксилазы и, вследствие этого, к повышению уровня глутаминовой кислоты и снижению содержания ГАМК. Повышенное содержание глутаминовой кислоты, обладающей эксайтотоксичностью, а также накопление ß-амилоида способствуют развитию митохондриальной дисфункции, увеличению содержания восстановленного НАД и, вследствие этого, к снижению активности НАД зависимой дейодиназы, что усугубляет местный гипотиреоз. Местный гипотиреоз, снижение концентрации биогенных аминов (норадреналин, дофамин), накопление $ß$-амилоида, полимеризация тау-протеина и высокое содержание глутаминовой кислоты в гомогенатах коры головного мозга способствуют снижению энергообразования, развитию гипометаболизма глюкозы, снижению активности АТФ-зависимой ацетилхолинтрансферазы, развитию холинэргического дефицита, нарушению когнитивных функций. Основываясь на литературных данных о развитии гипометаболизма глюкозы у пациентов с БА, можно предположить, что аналогичные выявленным нами изменениям обмена веществ в мозге имеют место и у людей, что обосновывает актуальность дальнейших исследований.

\section{Выводы:}

1) При моделировании болезни Альцгеймера у крыс, несмотря на системный эутиреоз, кора головного мозга находится в условиях гипотиреоза, о чем свидетельствует снижение трийодтиронина при несколько повышенном содержании тироксина в гомогенатах коры головного мозга.

2) У крыс при моделировании болезни Альцгеймера отмечается повышение глутаминовой и аспарагиновой аминокислот при снижении ГАМК, что, учитывая медиаторную роль этих аминокислот в условиях центрального холинэргического дефицита, может являться одним из важных факторов нарушения метаболизма при данной патологии.

3) При моделировании болезни Альцгеймера у крыс путем хронического внутрибрюшинного введения скополамина отмечается значительное снижение содержания норадреналина и дофамина в гомогенатах коры головного мозга, что способствует нарушению энергетического метаболизма и когнитивных функций.

4) Гистохимическое исследование ткани головного мозга крыс при постановке скополаминовой модели БА подтвердило образование амилоида в ткани головного мозга и стенках мелких артерий с параллельно развивающейся атрофией головного мозга.

Признательность: Исследование не поддерживалось какими-либо грантами. Авторы заявляют об отсутствии конфликта интересов.

\section{Литература}

1. Kumar A, Singh A, Ekavali. A review on Alzheimer's disease pathophysiology and its management: an update, Pharmacol Rep. 2015;67(2):195-203.

2. Taylor CA, Greenlund SF, McGuire LC et al. Deaths from Alzheimer's disease — United States, 1999-2014. Weekly. 2017;66(20):521-526.

3. Zagrebin V.L., Antoshkin O.N., Fedorova O.V., et al. Patogeneticheskie mehanizmy razvitija bolezni Al'cgejmera (Pathogenetic mechanisms of the developmet of Alzheimer's disease) [in Russian]. Vestnik VolGMU. 2016;3(59):7-12.

4. Craig LA, Hong NS, McDonald RJ. Revisiting the cholinergic hypothesis in the development of Alzheimer's disease. Neurosci Biobehav Rev. 2011;35(6):1397-409.

5. Hardy JA, Higgins GA. Alzheimer's disease: the amyloid cascade hypothesis. Science. 1992; 256(5054):184-5.

6. Selkoe DJ, Hardy J. The amyloid hypothesis of Alzheimer's disease at 25 years. EMBO Mol Med. 2016;8(6):595-608.

7. Maccioni RB, Farías G, Morales I et al. The revitalized tau hypothesis on Alzheimer's disease. Arch Med Res. 2010;41(3):226-31.

8. Tan ZS, Vasan RS. Thyroid function and Alzheimer's disease. J Alzheimers Dis. 2009;16(3):503-7.

9. Danysz W, Parsons CG. Alzheimer's disease, $\beta$-amyloid, glutamate, NMDA receptors and memantine--searching for the connections. Br J Pharmacol. 2012;167(2):324-52.

10. Martorana A, Koch G. Is dopamine involved in Alzheimer's disease? Front Aging Neurosci. 2014;6:252.

11. Mironova A.N. Rukovodstvo po provedeniju doklinicheskih issledovanij lekarstvennyh sredstv. Chast' pervaja. (Manual for carrying out preclinical researches of drugs. Part 1) [in Russian], Moscow: Grif i K; 2012.

12. Dejko RD, Shtrigol' SJu, Gorbach TV et al. Nootropni vlastivosti tetrapeptidu Acetyl-(D-Lys)-Lys-Arg-Arg-Amide (KK-1) na modeli hvorobi Al'cgejmera u shhuriv, zumovlenoï hronichnim vvedennjam skopolaminu (Nootropic properties of a tetrapeptide Acetyl-(D-Lys)-Lys-Arg-Arg-Amide (KK-1) using a model of Alzheimer's disease in rats caused by chronic scopolamine intake) [in Ukrainian]. Klinichna farmacija. 2016;20 (4):52-761.

13. Drozdov N.S., Materanskaja N.P. Praktikum po biologicheskoj himii (Practical guide on biochemistry) [in Russian], Moscow:Vysshaja shkola; 1998. 296 p. 
14. Trubicyna I.E., Drozdov V.N., Lazebnik L.B. et al. Pat. 2256920 Rossijskaja Federacija MPK G 01 N 33/50 Sposob opredelenija acetilholina (The way of acetylcholine determination) - 2003127761/15. Zajavl.: 27.03.2005. Opubl.: 20.07.2005 [in Russian]. - Bul. 20. -15 p.

15. Atack C, Magnusson T. A procedure for the isolation of noradrenaline (together with adrenaline), dopamine, 5-hydroxytryptamine and histamine from the same tissue sample using a single column of strongly acidic cation exchange resin. Acta Pharmacol Toxicol (Copenh). 1978;41(1):35-57.

16. 16. Sarkisov D.S., Perov Ju.L. Mikroskopicheskaja tehnika: rukovodstvo dlja vrachej i laborantov (Microscopic technique: a guide for physicians and laboratory assistants) [in Russian], RAMN; Medicina; 1996. 544 p.

17. Mendes-de-Aguiar CB, Alchini R, Decker H et al. Thyroid hormone increases astrocytic glutamate uptake and protects astrocytes and neurons against glutamate toxicity. J. Neurosci. Res. 2008;86(14):3117-25.

18. Bauer M, Heinz A, Whybrow PC. Thyroid hormones, serotonin and mood: of synergy and significance in the adult brain. Mol Psychiatry. 2002;7(2):140-56.

19. Atamna H, Frey WH. Mechanisms of mitochondrial dysfunction and energy deficiency in Alzheimer's disease. Mitochondrion. 2007;7(5):297-310

20. Kim JY, Kim N, Zheng Z et al. The $70 \mathrm{kDa}$ heat shock protein protects against experimental traumatic brain injury. Neurobiol Dis. 2013;58:289-95.

21. 21. Gorodetskaya IV, Bozhko AP, Bakhtina LY et al. Role of thyroid hormones in stress-induced synthesis of heat-shock proteins in the myocardium. Bul of Exp Biol and Med. 2000;130(12):1138-1140.

22. Hshieh TT, Fong TG, Marcantonio ER et al. Cholinergic deficiency hypothesis in delirium: a synthesis of current evidence. Bull Ex J Gerontol A Biol Sci Med Sci. 2008;63(7):764-72.

23. Lai TW, Zhang S, Wang YT. Excitotoxicity and stroke: identifying novel targets for neuroprotection. Prog Neurobiol. 2014; 115:157-88

24. Van de Ven AC, Muntjewerff JW, Netea-Maier RT et al. Association between thyroid function, thyroid autoimmunity, and state and trait factors of depression. Acta Psychiatrica Scandinavica. 2012;126 (5):337-384.

25. Santos NC, Costa P, Ruano D et al. Revisiting thyroid hormones in schizophrenia. J. Thyroid Res. 2012:569147 doi:10.1155/2012/569147

How to cite this article: Tatiana Gorbach, Galina Gubina-Vakyulyk, Oksana Nakonechna, Anton Tkachenko. Dynamics of changes in the content of thyroid hormones and some neurotransmitters in brain of rats with experimental Alzheimer's disease [in Russian]. J Clin Med Kaz 2017;4(46):26-32 